\title{
Interpreting the ECFA: A New Common Market for Taiwan and Mainland China?
}

Yen-Hsueh Lai*

The ECFA was signed by Taiwan and Mainland China on June 29, 2010. It is Taiwan's new overall national economic policy calling for rapproachment with Mainland China. A primary purpose of this Agreement is to establish a quasi national cross-strait common market within the framework of the WTO as well as to design the legal framework of bilateral economic cooperation. It is a course for the Chinese common market as the final economic integration. By its nature the current ECFA lies somewhat between a free trade agreement and a bilateral trade agreement within the framework of the WTO in the sector of trade in goods. Two parties have agreed on a new model of preferential treatment for goods exported from Taiwan to Mainland China. An agreed Early Harvest for Trade in Goods list is favourable for Taiwan, while an Early Harvest for Trade in Services list is balanced one for both parties. Other principles formulated by the ECFA are related to intellectual property rights and mutual investment. The success and failure of the ECFA will depend largely on the future cross-strait political atmosphere.

\section{Keywords}

ECFA, WTO, Early Harvest for Trade, Mutual Investment, Chinese Common Market

* Adjunct Lecturer of Law at Soochow University. LL.B./LL.M. (Soochow), Ph.D. (Xiamen). The author may be contacted at: yhlai31746242@yahoo.com.cn / Address: School of Law, Soochow University, 56, Kuei-yang St., Sec. 1, Taipei, Taiwan 100 R.O.C. 


\section{Introduction}

Scholars from Taiwan, Hong Kong and Mainland China have seen the need for a Chinese economic community or Chinese common market more than twenty years. ${ }^{1}$ While justifying intellectually and applauding the merits of the idea, however, government officials in Taiwan and Mainland China were grappling with political turbulence in Taiwan between 2000 and 2008, associated with the pro-independent Democratic Progressive Party ("DPP")'s years in power. That anomaly ended when Dr. Ma Ying-jeou was elected President of the Republic of China ("ROC"), Taiwan, on March 25, 2008, returning Taiwan to the Kuomintang ("KMT") fold and opening a new era between the government of the ROC of Taiwan and the government of the People's Republic of China ("PRC").

However, the timing of his taking oath as President of the ROC was not favorable for Dr. Ma. He was immediately challenged by a global financial crisis, mainly originating in the United States. Moreover, he had to solve a series of problems remaining from the former DPP government, including a continually worsening macro and micro island economy combined with a huge foreign debt, a relatively high rate of unemployment for the young generation and middle aged workers, inflation, stagnant investment and industrial output, and frozen salaries. To overcome such political, economic, and social obstacles the Ma Ying-jeou administration formulated a fresh overall national economic policy calling for cooperation with Mainland China in order to establish a quasi crossStrait common market within the framework of the World Trade Organization ("WTO") system. The new administration also designed a legal framework for bilateral economic cooperation for a "Chinese common market."

That blueprint has not proved easy to follow, mainly because of resistance from the opposing party and pro-independence elements in Taiwan, which do not accept political and economic change bringing the island closer to Mainland China. Even though some may recognize that cross-Strait economic cooperation would benefit the long term development of Taiwan's economy, it might further endanger their political stances in future general elections of Taiwan. Even after all these hardship, the new administration had no alternative but to implement the open-door policy toward Mainland China.

The Ma Young-jeou administration has explained reasons for economic cooperation with the Mainland China as follows. First, normalization of economic relations between

1 See Scholar Calls for a Mainland-HK-Taiwan Common Market, available at http://china.org.cn/English/2001/Feb/ 7845.htm (last visited on Mar. 16, 2011). 
Taiwan and Mainland China has been requested by the Taiwanese entrepreneurs established in Mainland China since 1987 when the ROC government officially abandoned its hostile policies toward Mainland China, which originated from the civil war (1945-9) period between the Communists and the Nationalists. A basis for export trade has long been established along the coastal provinces in Mainland China. Taiwanese manufacturers and exporters have needed to adopt a legal framework to guarantee their rights in Mainland China. An island-type economy of Taiwan depends largely on the man power and materials from China; the relatively cheaper labor force is essential for Taiwan exports toward global markets, while access to the mainland market is a 'prerequisite' for Taiwan to trade of goods and services. ${ }^{2}$

Second, Taiwan has limited diplomatic relations with major trading partners. For example, the limited relations have caused high cost of competitiveness against other Asian countries, particularly members of the Association of Southeast Asian Nations ("ASEAN"). 3 Therefore, without formal diplomatic relations, Taiwan finds it difficult to jump over the many hurdles that materially affect its overseas market in this region. ${ }^{4}$

Third, the marginalization of Taiwan by regional economic integration between China and ASEAN would adversely affect the economic ties between Taiwan and the countries of Southeast Asia, not only in investment, but also in economic cooperation in agriculture, industry, and advanced technology. 5

Fourth, the Chinese common market comprising Mainland China, Hong Kong, and Macau would replace an existing legal regime of four customs territories within the WTO. In today's multilateral trading system within the legal framework of the WTO, it is impossible to improve bilateral trade where there are different levels of economic development among member States, particularly between developed and developing

2 Paul S. P. Hsu, Taiwan, Mainland China, and the United States: Another Golden Triangle in Global Supply Chain 5 (May 2-4, 2002), paper presented to the $11^{\text {th }}$ Annual Conference, Committee of 100, San Jose, California, available at http//www.epoch.org.gtw/English/pdf/knowledge_03.pdf (last visited on Mar. 16, 2011).

3 See Bibliography on ASEAN, in P. SANDs \& P. KLein, Bowett's LaW of International Institutions 232 (6d ed. 2009); P. Kotler, H. Kartajaya, D.H. Hooi, Think ASEAN!: Rethinking Marketing toward ASEAN Community 2015208 (1 1 st ed. 2006); M.G. Plummken \& C.S. Yue, Realizing the ASEAN Economic Community: A Comprehensive ASSESSMENT, Institute of Southeast Asia Studies (Nov. 2009).

4 ROC Bureau of Foreign Trade, Taiwan External Trade Development Overview, available at http://cweb.trade.gov.tw (last visited on Mar. 16, 2011).

5 Shiou-chi Jing, East Asian Regional Economic Integration and the Development of China's Influence, available at http//www.cepd.gov.tw/dn.aspx"uid=1167 (last visited on Mar. 16, 2011); Shin-yi Chang, Analysis of the current East Asian Regional Economic Integration and Taiwan should be because of the Road, 2 EuR. J. INT'L REv. (2006); Konglian Gao \& Dai-sian Deng, Address the Marginalization of Taiwan's Economic Crisis, available at http//www.crosstrait.org/version1/subpage4/950407.pdf (last visited on Mar. 16, 2011); Siao-lin Wang, East Asia Regional Integration on the Economic Development of Taiwan Bay Plight and Coping Strategies, 456 E. AsIA REv. IssuE 6 (1996); Chi-chen Jiang, ASEAN-China FTA, and Taiwan should be Thinking of Strategies, available at http://cfee.nthu.edu.tw/=newsletters/series/4pdf/feature2_jiang.pdf (last visited on Mar. 16, 2011). 
countries. Article XXIV of the GATT provides that involved members of the WTO can create their own customs union or free trade areas under regional legal arrangements. ${ }^{6}$ In addition to the common market within the framework of the former European Economic Community ("EEC"),7 today's world is looking at the rapid growth in the European Free Trade Areas ("EFTA"), 8 the North American Free Trade Area ("NAFTA"), ${ }^{9}$ and other regional economic integration in Australasia, Americas (North, Central and North America), and Africa. Such regional constructs certainly reduce the advantages accorded to contracting parties of the WTO and have the potential to throw the principle of 'national treatment' and the "most-favor-nations treatment" into the waste basket. Taiwan enjoys no such alignments and should eagerly seek the alternative remedy other countries have found in bilateral free trade agreements ("FTAs"). The FTA, of course, is not an elixir for all economic ills. The success of the FTA is based solely on market opportunities, not a kind of friendly trade mark between two countries. For example, Taiwan signed FTAs with Panama, Guatemala, Nicaragua, Salvador and Honduras, but their commercial value was not worth more than classic bilateral commercial agreements because of lack of market opportunity. Therefore, Taiwan needs FTAs with major trading nations with high potential of market opportunity, particularly with members of ASEAN, the United States, Japan, Korea, Australia, and the European Union as a whole. To negotiate and sign such FTAs, Taiwan needs to improve its general bilateral relations with Mainland China. Otherwise, Beijing is expected to set political and diplomatic hurdles in Taipei's path, preventing any major trading countries from signing an FTA with Taiwan.

Taiwan has the double tasks of overcoming different political position of the PRC on the one hand. On the other hand, it should transform the island economy to mesh with a globalized web of production and promote trades with Mainland China. The best way

6 See J. Mathis, Regional Trade Agreements in the GatT/WTO: Article XXIV and the Internal Trade REQUIREMENT (2002); K. Case, Multilateralism Compromised: the Mysterious Origins of GATT Article XXIV, WoRLD Trade ReV. 1-30 (2006); J. McMillan, Does Regional Integration Foster Open Trade? Economic Theory and GATTS Article XXIV, in Regional Integration and the Global Trading system (K. Anderson \& R. Blackhurst eds., 1993), available at http://faculty-gsb.stanford.edu/mcmillan/personal_page/documents/Does\%20Regional\%20Ingtegration\% 20Foster\%20open\%20Trade.pdf (last visited on Mar. 16, 2011). See also Bibliography, in K. SAGGI \& M. YILDIZ, ARTICLE XXIV OF THE GATT: GooD, BAD, OR BоTH?, available at http:economics.ca/2004/papers/0241.pdf last visited on Mar. 16, 2011); Lorand Bartel, 'Interim Agreements' under Article XXIV GATT, 8 WoRLd TRAdE REv. 339-350 (2009).

7 H.C. Wang, The Legal Regime of Regional Economic Organizations 70-73 (2007).

8 Figures, Legal Aspects of the European Free Trade Association, 14 INT' L \& ComP. L.Q. 1079 (1965); Sands \& Klein, supra note 3, at 190-191; Wang, id. at 76-77.

9 See Bibliography on NAFTA, in Sands. \& Klein, id. at 226-227; Wang, id. at 135-139; R.H. Folsom, M. GoRdon, \& D. Ganatza, NAFtA and Free Trade in the Americas: A Problem-Oriented Coursebook (2d ed. 2005); G.C. Hufbauer \& J.J. Schott, NAFTA Revisited: Achievements and Challenges (Institute for International Economic Research, Washington D.C., 2005); Folsomk, R. H., NAFTA and Free Trade in the Americas in a Nutshell (3d ed. 2008). 
to go for Taiwan is to normalize political relations with Mainland China first, then integrate Taiwan's economy into the continent's economic system. Taiwan's new policy towards Mainland China reflects this idea.

Meanwhile, the motives of Mainland China to conclude a cross-Strait bilateral economic cooperation agreement with Taiwan are quite political. Mainland China regards the economic crisis of Taiwan as an opportunity not only to extend its assistance to Taiwan to overcome such economic problems, but also to consolidate existing friendly ties with the ruling Kuomintang party and accelerate final unification with Taiwan. Of course, any interaction will be based on the "One-China Policy repeatedly announced by the PRC Government on various occasions." 10

Based on the above-mentioned circumstances, the historical Economic Cooperation Framework Agreement ("ECFA") was formally concluded between Taiwan and Mainland China on June 29, 2010 in Chongqing, China. 11 The ECFA send positive signals that Taiwan and China are now forging future economic cooperation that will build a stronger economic partnership and set the pace for brining the region out of the current economic crisis.

This paper mainly deals with the legal problems of the ECFA within 4 parts. Part II will analyze the new goods-trading system under the ECFA. This part shows why and how Taiwan would gain more benefit from trade than Mainland China. Part III will investigate the new system of trade in services between Taiwan and Mainland China and its contingency under the WTO system. Part IV examines trade-related aspects of international intellectual property rights and the problem of mutual investment. Part $\mathrm{V}$ explores the coming stages of the ECFA development. Here, the author will discuss both the chances for advancing a Chinese common market and its implementation within the framework of the WTO. In conclusion, the author will indicate the immediate consequences of the new mechanism of the ECFA for Japan, Korea, and the ASEAN.

\section{ECFA for Trade of Goods}

The recently concluded ECFA lies in somewhere between a free trade agreement and a

10 For example, the first One-China Principle was declared by Jiang Zemin, General Secretary of the Central Committee of the Communist Party of China and President of China in an "Eight-point Proposal" which emphasized the continuance of striving toward the reunification of China, available at http://www.gwytb.gov.cn:8088/ detail.asp?table=JiangEP\&title=Jiang+Zemin's+Eight-point+Proposal\&m_id=17 (last visited on Jan. 10, 2011).

11 Cross-Strait Economic Cooperation Framework Agreement ( "ECFA"), available at http://www.ecfa.org.tw/ EcfaAttachment/ECFADoc/ECFA.pdf (last visited on Jan. 10, 2011). 
bilateral trade agreement within the framework of the WTO. It would ameliorate the cross-strait hostilities and further aims to legalize bilateral trade exchange and cooperation between the two sides under the frame of the WTO. As a free trade agreement, Taiwan and Mainland China agreed in the ECFA as follows: "to strengthen and advance the economic, trade and investment cooperation between the two parties"; 12 "to gradually reduce or eliminate barriers to trade and investment for each other"; 13 to promote "further liberalization of trade in goods and services"; 14 and "to expand areas of economic cooperation and establish a cooperation mechanism." 15 Generally, the ECFA reaffirms already-established principles under the WTO law, offering little new there.

In the sector of trade in goods, however, the two parties have agreed on a new model for preferential treatment of goods exported from Taiwan to Mainland China. "Early Harvest for Trade in Goods List" covers 539 Taiwanese products and 267 Mainland Chinese goods. 16 The advantage to Taiwan is expected to amount to USD 13.8 billion, while Mainland China expects to receive benefits of USD 2.86 billion. The Early Harvest Program with respect to the goods listed in Annex I of the ECFA will be implemented within six months after the entry into force of the ECFA.17 Based on the disparity advantages to each side, it would seem that the tariff concession in the Early Harvest for Trade in Goods does not on the surface comply with the principles of equality and reciprocity. 18

The provisions of the ECFA for trade in goods have to be interpreted in accordance with the following: "the basic principles of the WTO" and other principles of the GATT in the Agreement on Rules of Origin; the Agreement on Technical Barriers to Trade ("TBT Agreement"); the Agreement on the Application of Sanitary and Phytosanitary Measures ("SPS Agreement"); the Agreement on Implementation of Article VI of the GATT and GATS 1994; the Agreement on subsidies and Countervailing Measures; and the Agreement on Safeguards and trade remedy measures. All are applied mutatis

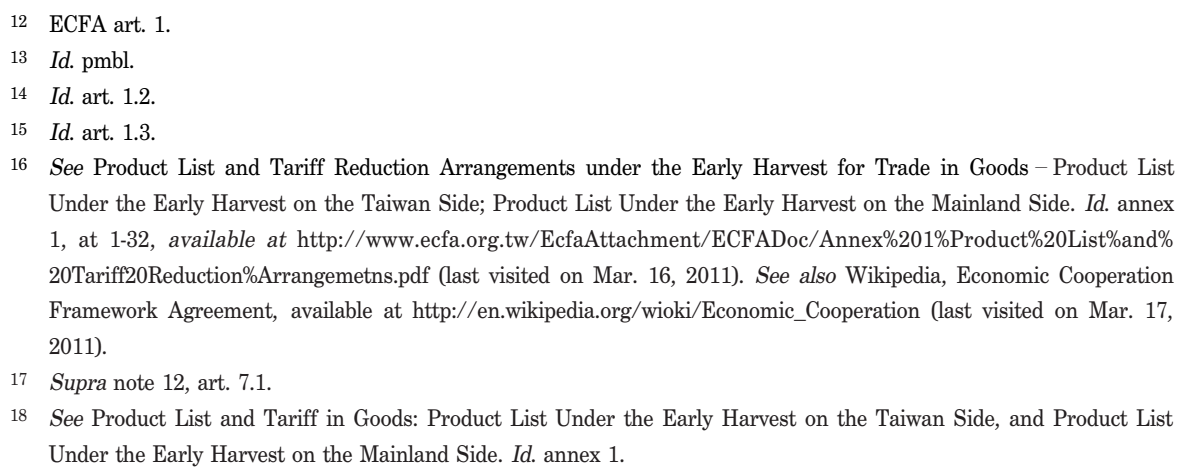

18 See Product List and Tariff in Goods: Product List Under the Early Harvest on the Taiwan Side, and Product List Under the Early Harvest on the Mainland Side. Id. annex 1. 
mutandis. 19

The problem lies in applying the principle of national treatment, most-favorednation treatment as well as other preferential treatment contained in the GATT. Mainland China is unwilling to recognize Taiwan as a sovereign state under international law. Legally speaking, the Government of ROC still acknowledges the principle that "there is but one China and Taiwan is a part of China." 20 However, the two governments have been competing each other as the sole legitimate government representing China for more than half a century. It is undeniable that there are at least twenty three sovereign States (including the Holy See) maintaining their diplomatic ties with the Taiwan recognizing the ROC Government as the sole legal government representing China although it was expelled from the United Nations in 1971.21 The signatories of the ECFA sidestepped this sensitive political problem and have not touched the political identity of two contracting parties fundamentally. In this case, 'national' should be interpreted as "people' of each side under "One China principle," but the two parties may invoke the most-favored-nations treatment under the condition that "any advantage, favor, privilege or immunity granted by [ECFA] contracting party to any product originating in or destined for any other country shall be accorded immediately and unconditionally to the like product originating in or destined for the territories of all other contracting parties." 22

Interpretation of the ECFA on trade in goods is not limited to the application of principles already established by the multilateral agreements of the WTO. Determining the rights and obligations of two parties must take into consideration of other relevant declarations and decisions of the WTO and recommendations or rulings delivered by the Panels and Appellate Review of the WTO's Dispute Settlement Body ("DSB"). For example, the two parties of ECFA have to follow the Codex Alimentarium as a part of international food law developed and adopted jointly by the Food and Agriculture Organization ("FAO") and the World Health Organization ("WHO"),23 because the SPS Agreement "gives privileged status, for purposes of the WTO regime, to government standards based on the FAO-WHO's Codex Alimentarius." 24 Another example is the

19 Id. art. 3.

20 According to Article 4 of the Constitution of the ROC, the territory of the ROC includes all China, not just Taiwan.

21 G.A. Res. 2758, available at http://en.wikipedia.org/wiki/United_Nations_General_Assem (last visited on Jan. 10, 2011).

22 GATT art. 1. Taiwan and Mainland China are members of the WTO, the principle of general most-favoured-nation treatment is also applied to bilateral trade relations between Taiwan and Mainland China.

23 B.C. Nirmal, International Food Law and Food Safety, 7 SoocHow L. J. 1-40 (Jan. 2010); Chia-Jui Cheng, The Progressive Development of International Food Law Through the United Nations, Its Specialized Agencies and Other International Organizations, 6 SoocHOw L. J. 17-135 (July 2009).

24 Jose E. AlVAREZ, INTERNATIONAL ORGANIZATIONS As LAW-MAKERs 220-223 (2005). 
international standardization adopted by the International Standardization Organization ("ISO"). The TBT Agreement presumes that "governmental standards that adhere to those produced by the ISO are presumptively legitimate and not contrary to WTO law." 25

\section{ECFA for Trade in Services}

An important motive behind the ECFA is that Taiwan urgently needs to enter the Chinese mainland market in the sector of trade in services. The two parties agreed to open service markets, to "gradually reduce or eliminate restrictions on a large number of sectors in trade in services," 26 and to "further increase the breadth and depth of trade in services." 27 A list of the Early Harvest for Trade in Services was adopted and it was agreed that "the Early Harvest Program shall be implemented expeditiously after the entry into force" of the ECFA." 28

An important principle of trade in services in the ECFA is that each party is obliged to reduce or eliminate restrictive measures affecting the services and service suppliers of the other party. ${ }^{29}$ This principle includes business services in non-financial service sectors and the financial services sector. The former non-financial sectors include: research and development services; convention services; exhibition services, specialty design services; communication services; distribution services; recreational cultural and sporting services; and air transport service. The latter financial services sector include: insurance and insurance-related service; banking and other financial services (excluding securities, futures and insurance), and securities, futures and other related services. Mainland China opens eleven service sectors for Taiwan, while Taiwan allows wider access to seven areas, including banking and movies. 30

\footnotetext{
Id. at 220 .

Supra note 12, art. 4. 2(1).

Id. art. 4. 2(2).

Id. art. 8. 1.

9 Id. annex IV, available at http://www.ecfa.org.tw/EcfaAttachment/ECFADoc/Annex\%20IV\%20Sectors\%20and\% 20Liberalization\%20Measures.pdf (last visited on Jan. 10, 2011).

30 Id. annex IX - Sectors and Liberalization Measures under the Early Harvest for Trade in Services: Commitments of the Taiwan Side on Liberalization of Non-Financial Service Sectors (at 1-12); Commitments of the Taiwan Side on Liberalization of Financial Services Sector (at 4-8); Commitments of the Mainland Side on Liberalization of Nonfinancial Service Sectors (at 5); and Commitments of the Mainland Side on Liberalization of Financial Services Sector (at 9-10), available at http://www.ecfa.org.tw/EcfaAttachement/ECFADoc/Annex\%20IV\%20Secctors\%20and\% Liberalization\%20Measures.pdf (last visited on Mar. 17, 2011).
} 
The principles established by the General Agreement on Trade in Services ("GATS") are rather flexible in allowing developing countries to negotiate specific commitments pursuant to the principles of specific commitments on market access and national treatment contained in Parts III and IV of GATS. It is required to give special consideration to the interests of the developing and least developed countries. 31 The process of liberation shall take place with due respect for national policy objectives and the level of development of individual members, both overall and in individual sectors. 32 There shall be appropriate flexibility for individual developing country members to open fewer sectors, to liberalize fewer types of transactions, to progressively extend market access in line with their development situation, and, when building markets available to foreign service suppliers, to attach access conditions aimed at achieving the objectives referred to in Article IV of the GATT.33 In this sense, a legal problem between Taiwan and Mainland China is apparent. The latter claims itself as developing country, while the former, a developed one. The legal difficulties ensuing can be eliminated if two sides reach consensus on an internal market under a common market regime. At present and even for foreseeable future, Taiwan is reluctant to open business services sectors to Mainland China because it would regard this policy as contravening principle of equality and reciprocity under the WTO law. Any conflict of interests will be subject to consultation between the two parties within the mechanism of the Cross-Strait Economic Cooperation Council which is empowered to settle any dispute over the interpretation, implementation and application of the ECFA. 34

\section{ECFA Relating to Intellectual Property Rights and Mutual Investment}

The international legal regime on intellectual property rights and investment has been highly controversial between developed and developing countries since the end of World War II. International intellectual property law is mainly based on three systems, namely the Paris Union on the protection of industrial property, 35 the Berne Union on the protection of copyrights and other neighboring rights, 36 and the Geneva Union for

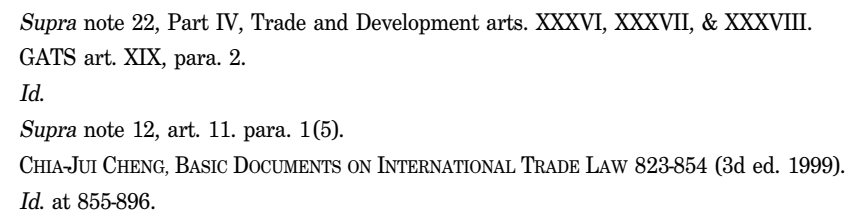


the Protection of New Varieties of Plants ("UPOV").37 Furthermore, the WTO Agreement on Trade-Related Aspects of Intellectual Property Rights ("TRIPs") 38 fills sanction mechanism that lacks in those systems.

\section{A. The ECFA and Intellectual Property Right Protection}

Under the ECFA, a cooperation agreement on intellectual property protection was signed simultaneously with the ECFA itself. A frame agreement also provides protection for patent, trademark, copyrights and new varieties of plants. Certain principles adopted by international intellectual property law are also applied to the principle of national treatment, the principle of the mot-favored-nation treatment, priority, principles of domicile, etc. Although the Cross-Strait Protection of Intellectual Property Rights Cooperation Agreement has mentioned neither the systems under the management of the World Intellectual Property Organization ("WIPO") nor the TRIPs system, both would apply to Taiwan and Mainland China. Problems between the two parties lie in the area of domestic laws. Mainland China has internationalized its domestic intellectual property law by adopting the Paris, Berne, and Geneva systems of intellectual property law, while Taiwan is not a party to them. In addition, Taiwan has not adopted the law to protect new varieties of plants, while Mainland China adopted domestic law protecting new varieties of plants although it has not ratified the International Convention for the Protection of New Varieties of Plants ("UPOV") adopted in Paris on December 2, 1961. In sum, there is a possibility of normative conflict on the three levels of intellectual property law, namely, international, national, and regional. New rules of law need to be adopted to settle the conflicting elements of the current cross-Strait protection of intellectual property rights.

\section{B. The ECFA and the Promotion and Protection of Investment}

The promotion and protection of foreign investment is often a political problem of developing countries. Multilateral investment instruments such as the OECD Draft Convention on the Protection of Foreign Property in 196739 and the Draft Multilateral

37 Union Internationale pour la Protection des Obtentions Végétales [International Union for the Protection of New Varieties of Plants ("UPOV")] is an intergovernmental organization based in Geneva, available at $\mathrm{http} / /$ /en.wikipedia.org/wiki/International_Union_for_the_Prot (last visited on Jan. 10, 2011).

38 The full text of TRIPS in WTO, The Legal Texts: The Results of the Uruguay Round of Multilateral Trade NEGOTIATIONS 321-353 (1999).

39 In 1962 the OECD released the Draft Convention on the Protection of Foreign Property, which was revised and approved by the OECD in 1967 ("1967 Draft OECD Convention"). The 1967 Draft Convention generally reflects the views of the capital exporting states on the minimum standards of investment. The full text of the Draft Convention, available at http://www.oecd.org/LongAbstract/0,3425,en_2649_337837 (last visited on Jan. 10, 2011). 
Agreement on Investment ("MAI")40 in 1995 were rejected by most developing countries, including China. Old model of PRC investment agreements signed with other countries were protective of China's interests. In 1988, China changed its policy of foreign direct investment ("FDI") to protect Chinese overseas FDIs, establishing a model agreement incorporating a second generation of Chinese investment policy in 2003. It reflected the country's very considerable gains in foreign reserves in hand. 41 Indeed, from 2003 to 2009, China jumped to the second world trading power, transforming itself into both importer and exporter of investment capital and technology. China is now the largest foreign investing country. The strong reaction in the past to the OECD's model law of investment has been softened; China even signed an investment agreement with ASEAN on August 15, 2009, in Bangkok,42 symbolizing what would be considered as a third generation of the PRC model agreement for investment. The latest model may provide the good example for Taiwan and China to follow in the next few months when negotiating to sign an agreement on promotion and protection of investment.

Salient features of the China-ASEAN model agreement on investment can be summarized as follows:

First, the definition of 'investment' was enlarged to include: (1) movable and immovable property and any other property rights such as mortgages, liens or pledges; (2) shares, stocks and debentures of juridical persons or interests in the property of such juridical persons; (3) intellectual property rights, including rights with respect to copyrights, patents and utility models, industrial designs, trademarks and service marks, geographical indications, layout designs of integrated circuits, trade names, trade secrets, technical processes, knowhow and goodwill; (4) business concessions conferred by law, or under contract, including concessions to search for, cultivate, extract, or exploit natural resources; and (5) claims to money or to any performance having financial value. ${ }^{43}$ Moreover, returns that are invested are to be treated as investments, and any alteration of the form in which assets are invested or reinvested shall not affect their character as investments.

40 Negotiations on a proposed multilateral agreement on investment ("MAI") were launched by governments at the Annual Meeting of the OECD Council at Ministerial level in May 1995. The objective was to provide a broad multilateral framework for international investment with high standards for the liberalization of investment regimes and investment protection and with effective dispute settlement procedures, open to non-OECD countries.

41 Most important of all, China signed first internationalized BIT with Barbedo in 1998 in which China changed its practice of limiting investor-State arbitration to dispute concerning the amount of compensation resulting from expropriation and consented generally to the arbitration of IIA disputes. See A. NEWCOMBE \& L. PARADELL, LAW AND Practice of Investment Treaties: Standards of Treatment 56 (2009).

42 The Agreement on Investment of the Framework Agreement on Comprehensive Economic Co-operation between the Association of Southeast Asian Nations and the People's Republic of China (ASEAN-China Investment Agreement 2009), available at http://www.aseansec.org/22974.pdf (last visited on Jan. 10, 2011).

43 Id. art. 1(d). 
Second, national treatment covers the management, conduct, operation, maintenance, use, sale, liquidation, and other forms of disposal of such investments.44

Third, the contracting parties are given the most-favored-nation treatment with respect to admission, establishment, acquisition, expansion, management, conduct, operation, maintenance, use, liquidation, sale, and other forms of disposal of investments. 45

Fourth, as to treatment of investment, each party shall accord fair and equitable treatment and full protection and security. The former refers to the obligation of each party not to deny justice in any legal or administrative proceedings, while full protection and security requires each party to take such measures as may be reasonably necessary to ensure the protection and security of the investment of the other party's investors. 46

Fifth, expropriation, nationalization or any other measure of expropriation against investments are prohibited, unless the following conditions are met: for a public purpose; in accordance with applicable domestic laws including legal procedures; carried out in a non-discriminatory manner and on payment of compensation. 47 The compensation must follow international standard for promptness, adequacy, and effectiveness based on the fair market value of the expropriated investment at the time when expropriation was publicly announced or when expropriation occurred, whichever is earlier, and it shall be freely transferable in freely usable currencies from the host country. 48

Sixth, transfer and repatriation of profits are guaranteed, including the initial capital, plus any additional capital used to maintain or expand the investments as well as other income from investment. 49

Seventh, it is allowed to take measures to safeguard the balance of payments of contracting parties in the event of serious balance of payments and external financial difficulties or threat thereof. 50

Eighth, the system of subrogation is accepted by ASEAN and China in the event that any Party or any agency, institution, statutory body or corporation designated by it, as a result of an indemnity it has given in respect of an investment or any part thereof, makes payment to its own investors in respect of any of their claims under the

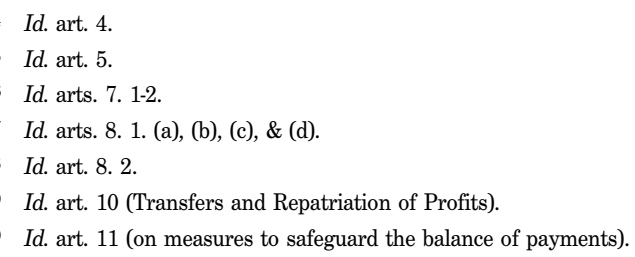


Agreement. The other Parties concerned shall acknowledge that fact, and these entities of subrogation are entitled to exercise the rights and assert the claims of as investors.

Ninth, except for promotion of investment clauses 51 and transparency clauses, 52 there are several other categories of exceptions for investors, in which investors' rights would be restricted, such like denial of benefits, general exceptions, and security exceptions.

Last, dispute settlement mechanisms for foreign investment have been accepted by China. In addition to negotiating and consulting two parties are allowed to submit their case to the courts or to administrative tribunals of the disputing party; 53 to the International Centre for Settlement of Investment Disputes ("ICSID") Convention under ICSID Rules of Procedure for Arbitration proceedings; 54 under the ICSID Additional Facility Rules; 55 and under the rules of the United Nation Commission on International Trade Law ("UNCITRAL").56 International conciliation and arbitration procedures are accepted by China and ASEAN. It is a big step for China to follow these international investment dispute settlement systems.

Current negotiations between Taiwan and Mainland China on the investment agreement for promotion and protection within the framework of ECA have been complicated by the question of which models are to follow during the political tests ahead. Taiwan may want more protection clauses of its enterprises in Mainland China, not-more-clauses on two ways investment promotion, because the Taiwanese are concerned about huge capital sums pouring into Taiwan from Mainland China.

So far as the Preamble of the ECFA is concerned, the two parties have stressed the necessity of advancing the investment and their decision to conclude an agreement for promotion and protection of investment. The following are guidelines:

1) establishing an investment protection mechanism;

2) increasing the transparency of investment-related regulations;

3) gradually reducing restrictions on mutual investments between the two Parties; and

4) promoting investment facilitation.

Before signing a bilateral investment agreement between Taiwan and Mainland China, they should compromise each other in accordance with the China-ASEAN model investment agreement to solve several problems of a conceptual and political nature.

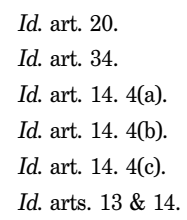


First, subject matter has to be clarified, namely, the political status of Taiwan vis-à-vis Mainland China. If an agreement is signed under the name of the Cross-Strait Exchange Foundation and the Association for Relations Across the Taiwan Straits ("ARATS"), the investment agreement could be regarded as a contractual one, and there will be less procedural problems. Delegations of power to sign the ECFA should be clearly identified for the sake of legal effects. The effective enforcement of the agreement should also be taken into considerations.

In bilateral investment treaties ("BITs"), the modern investment clauses should be essentially included as follows: definitions of investor and investment; conditions for admission of investments and their establishment, standards of investment protection (including fair treatment, full protection and security, the Umbrella Clause,57 access to justice, fair procedure, and denial of justice, emergency, necessity, armed conflicts, and force majeure, preservation of rights, arbitrary or discriminatory measures, the national treatment or minimum treatment of international law, MFN treatment and transfer of fund), subrogation, expropriation and compensation system, and finally the dispute settlement mechanism. 58 The China-ASEAN model tracks the same topics, although the interpretation of some clauses is controversial. The contents of investment clauses for Taiwan and Mainland China may follow the model agreement between ASEAN and China, if Taiwan hopes to integrate fully itself into not only the Mainland Chinese market, but also the ASEAN markets as a whole.

In the past, Mainland China did not accept certain investment clauses demanded by western powers, particularly with regard to the liberalization of investment markets. China preferred one-way investment from abroad under the administrative control of government. It is still very sensitive to clauses relating to the 'minimum standard' 59 of international law and dispute settlement mechanisms in investment agreement. E.g., Mainland China would not accept arbitration through ICSID. Moreover, the PRC Model

57 A typical clause reads as follows: "Either Contracting Party shall constantly guarantee the observance of the commitments it has entered into with respect to the investments of the investors of the other Contracting Party." See The Pakistan-Switzerland BIT art. 11. The second type of Umbrella Clause reads as follows: "Each Contracting Party shall observe any obligation it has assumed with regard to specific investments in its territory by investors of the other Contracting Party." See The Philippines and Switzerland BIT art. X.2, cited by Vaughan Lowe, Changing Dimensions of International Investment Law, 1 Collected Courses of the XiAmen ACAdEMy of International LaW 463-465 (2006). The third type of Umbrella Clause reads as follows: "Each Party shall observe any commitments it may have entered into with the investors of another Party as regards to their investments." See Agreement on Investment of ASEAN-China in 2009 art. 18.2, available at http://fta.mof.com.gov.cn/inforimages/200908/ 20090817113007764.pdf (last visited on Jan. 10, 2011).

58 R. DolZer \& C. Schreuer, Principles of International Investment LaW (2008).

59 T. Yalkin, The International Minimum Standard and Investment Law: The Proof is in the Pudding, EJIL ANALYSIS, available at http://www.ejiltalk.org/international-minimum-standards (last visited on Mar. 16, 2011). See also Dolzer \& Schreurer, id. at 11-16. 
BIT of 2003 includes articles on definitions, promotion and protection of investment, treatment of investments, expropriation, compensation for damages and losses, transfers, subrogation, settlement of disputes between contracting parties and settlement of disputes between investors and one contracting party. 60 However, these are not general types of globalized investment agreement.

Moreover, expropriations and compensation problems remain controversial issues in the cross-Strait investment. Mainland China is not really ready to follow the recognized principle of international law in which expropriation must be in the public interest, without discrimination on the basis of nationality, and accompanied by the "prompt, adequate, and effective compensation," which has been confirmed repeatedly by both the Permanent Court of International Justice ("PCIJ") and the International Court of Justice ("ICJ"). 61 However, Mainland China still insists that cross-straits relations be internal affairs within the sovereignty of China and that any reference to international law might be harmful to such sovereignty. As far as disputes are concerned, China is willing to propose and accept a compromise-based settlement mechanism rather than a court or tribunal.

Consequently, it would be more realistic and promising to create a new cross-strait mixed commission of conciliation and arbitration to handle dispute cases, instead of relying on national or international arbitral tribunals.

\section{Cross-Strait Common Market - Myth or Reality?}

Regional economic integration takes various forms and modalities containing geopolitics, geographical proximity, history, cultural and ethnic or racial elements. The creation of the European Union would be the best example of such considerations, which set different stages of development in accordance with Article 2 of the Treaty

60 The full text of the Agreement between the Government of the People's Republic of China and the Government of [...] on the Promotion and Protection Investments can be found in Dolzer \& Schreuer, id. at 352-359.

61 In its Judgment in the Chorzow Factory (Jurisdiction) proceedings, the PCIJ stated that: "It is a principle of international law that the breach of an engagement involves an obligation to make reparation in an adequate form. Reparation therefore is the indispensable complement of a failure to apply a convention and there is no necessity for this to be stated in the convention itself."

In the Judgment on the Chorzow Factory (Indemnity) the Court said: "It is a principle of international law, and even a general conception of law, that any breach of an engagement involves an obligation to make reparation. In Judgment No. 8 ...the Court has already said that reparation is the indispensable complement of a failure to apply a convention, and there is no necessity for this to be stated in the convention itself." See Chorzow Factory (Jurisdiction), P.C.I.J (ser. A) No. 9, at 21 (1927) \& Chorzow Factory (Indemnity), P.C.I.J (ser. A) No. 17, at 29 (1928). For details, see I. Brownlie, Principles of Public International LaW 435 (7th ed. 2008). 
Establishing the European Economic Community of 1957.62 The principal task of the common market is to coordinate the economic policies of the contracting parties. To that end, the common market lays down the elements of its operation and defines policies which, when implemented, would move from the stage of the common market to that of an economic community.

The cross-Strait common market would have a different blueprint from the European common market designed by Robert Schuman and Jean Monnet, who tried to realize an "État-Unis d'Europe" (Unites States of Europe). 63 Nevertheless, the way to the European Union may serve as a guideline leading to the final unification of Taiwan and Mainland China as a supranational union, lying somewhere between confederation and federation. 64 The ECFA would play a constructive role in grounding the first stage of economic integration, which is expected to be followed by political integration in the future.

A common market may be divided into three patterns. 65 A free trade area is the first stage. Then, the two independent customs territories would be transformed into a single customs territory and a single internal market, a regional economic cooperation community, customs union, and a free trade area. A Chinese Common Market as a single 'internal' market should embrace the Hong Kong and Macau customs territories as well as Taiwan. Thus, the common market territory is marked out by the political frontiers of the contracting parties. Within these frontiers, their markets are freely transacting in the context of a 'directed economy.' Basically, any internal common market has to comprise the freedom of movement of goods, persons, services and capital as well as the common policies of commerce, agriculture and competition.

In that sense, however, the ECFA is not a complete FTA in comparison to the European Common Market agreement, because it only touches commercial freedom, without political integration. A political purpose has been declared repeatedly through different levels of PRC officials.66 Mainland China continues to expect some form of

62 P. Craig \& G. De Burca, EU Law: Text, Cases, and Material 1200 (3d ed. 2002); T.C. Hartley, The Foundation of European Community LaW (4th ed. 1998); R.H. Folson, Principles of European Union LaW 568 (Feb. 2005); Steiner, J. \& Woods, L., EU LAW 790 (Nov. 2009).

63 See Schuman Declaration (May 9, 1950). For details on the French Governmental proposal made by then - French Minister of Foreign Affairs Robert Schuman, see Wikipedia, available at http://en.wikipedia.org/wiki/ Schuman_Declaration (last visited on Jan. 10, 2011); See also Henri Rieben, Un Changement D'esperance, LA Declaration du 9 Mai 1950 (2000); Robert Schuman, Pour L'europe (Paris, 1963); J. Lecerf, Histoire de L'unité EUROPÉENNE 6 (1965).

64 See Supranational Union, available at http://en.wikipedia.org/wiki/Supranational_union (last visited on Jan. 10, 2011).

65 ERIC Y.J. Lee, Legal Issues of Inter-Korean Economic CoOperation Under the ARMistice System 245-252 (2002).

66 The latest was uttered by Wangyi, Director of Taiwan Affairs Council of PRC State Council, who invoked the sayings of Dr. Sun Yat-sen, founding father of the ROC in 1911, in emphasizing the "Restoration of Taiwan and 
reunification with Taiwan.

Several objectives are structurally envisaged by implication as necessity to form a Chinese Common Market in the first stage. Under the economic cooperation clauses of the ECFA, the two parties have agreed to strengthen cooperation in the areas of the liberalized trade in goods and services, intellectual property rights protection and cooperation, customs cooperation, trade promotion and facilitation, financial cooperation, industrial cooperation and other sectors relevant to the formation of a common market.

In the historical as well as political sense, a cross-Strait common market would be the key to one of most vexing challenges of the contemporary world. In addition, this common market has a political raison d'être, because the progression of a common market would lead to political integration as seen in the course of establishing the European Union. In this process, the ECFA will function significantly, since their agreement would guide the two sides to forward with reciprocity and solidarity. The ECFA will provide the institutional framework of the Economic Cooperation Council which will be divided into seven bureaus to handle relevant matters under the ECFA. 67 The new economic relations established under the ECFA's institutional framework will lay down policies as well as the rules for implementation and enforcement.

\section{Conclusion}

The signing of the cross-Strait ECFA marks a watershed rapprochement between the Chinese Communist Party and the Taiwan's Nationalist Kuomintang Party. Taiwan aims to improve its political and economic ties with Mainland China in keeping with the new Chinese policy of Ma Ying-jeou government under the slogan, "no unification, no independence, no use of force." 68 The elements of the new economic policy toward the mainland China constitute a new system of trade in goods and services, the protection of intellectual property rights, and the promotion of mutual investment. The bilateral trade of goods and services is primarily interpreted according to basic rules of the WTO, supplemented by new tariff concessions for goods specified in an "Early Harvest for

Consolidation of Chinese [China]." See Wangyi, Director of ARATS, Address at Dr. Sun Yatsen Forum organized in Guangzhou, China (Dec. 16, 2010). See ChinA Time, Dec 17, 2010, at A 22 .

67 See China Time (Taipei), Dec. 14, 2010, at A.12.

68 Frank Muyard, Ma Ying-jeou's New Chinese Policy, RESEAU AsIE, Nov. 1, 2008, available at http://www.reseauasie.com/edito-en/reseau-asie-s-editorial/taiwan-china-relations-ma-ying-jeou-s-new-chinese-policy-by-frank-muyarddirector-of-the-taipei-offi (last visited on Mar. 20, 2011). 
Trade in Goods" agreement and the elimination of restrictive measures in force affecting services and service suppliers covered in an "Early Harvest for Trade in Services" agreement.

The ECFA also deals with protection for patents, trademarks, copyrights and new varieties of biological plants within both frameworks of the WIPO and the WTO. Still another aspect of the ECFA lays a foundation for conducting a new round of negotiations for the promotion and protection of new investments. The additional negotiations are necessary because Taiwan has been reluctant to allow the PRC investors to enter Taiwan due to the pressure from the opposition party. However, such an agreement should be reached in the foreseeable future.

So far as the establishment of a cross-Strait common market is concerned, it is not a fond hope but a reality soon achievable in the future. A supportive basis for an integrated common market already exists because Taiwan has become the number one foreign investor in Mainland China and major Taiwanese production lines have already been installed in various provinces of the PRC. 69

The ECFA should have a crucial positive influence on cross-Strait relations in various sectors. While Taiwan is focused on expanding its exports to Mainland China, the ECFA should provide a firm basis for economic and social integration of the two sides in the long run, further consolidating a stabilized peace in East Asia and establishing a new triangle of economic ties among Taiwan, China and the ASEAN.

The ECFA also stands to give Taiwan more chances to expand its trade volume with other Asian countries including ASEAN members through bilateral FTAs. For example, Singapore and Taiwan have just announced a new round of negotiations on an Agreement between Singapore and the Separate Customs Territory of Taiwan, Penghu, Kimen and Matsu on Economic Partnership ("ASTEP"). ${ }^{70}$ India has followed in Singapore's steps and Taipei has already set an agenda for FTA negotiations with New Delhi. 71

According to the statistics released from National Bureau of Statistics of China, Taiwan is the seventh investor from abroad. The statistics from the General Administration of Customs of China shows that the importing goods from Taiwan to China is the third rank among all countries. It was also published by Investment Commission of Ministry of Economic Affairs, ROC, the approved investment amount is as high as reaching 146 millions U.S. dollars. Based on the statistics of Ministry of Finance of ROC, it was reported that Mainland China is the second importing country of Taiwan, available at http://2k3dmz2.moea.gov.tw/gnweb/Indicator/wFrmIndicator.aspx\#B (last visited on May 9, 2011).

70 S. Hwal, Singapore, Taiwan to Launch Trade Talks, The STRAits Times (Singapore), Dec. 12, 2010. See also Singapore Set for Formal Talks on Trade Deal, CHINA Post (Taipei), Dec. 16, 2010, available at http://www.chinapost.com.tw/ taiwan-business/2010/12/16/283 (last visited on Mar. 18, 2011).

71 M. Swire, Taiwan, India Begin FTA Feasibility Study, TAX-News. Com, Hong Kong, Mar. 10, 2011, available at http://www.tax-news.com/news/Taiwan_India_Begin_FTA_F (last visited on Mar. 18); See also Taiwan and India Begin Exporting Feasibility of a Free Trade Agreement, CHINA Post, Mar. 9, 2011, available at http://www.chinapost.com/ tw/business/asia/asian-market/2011 (last visited on Mar. 18, 2011). 
With the ECFA, both Taiwan and Mainland China are expected to be competitive with other Asian and non-Asian countries. If implemented, the ECFA will reinforce national strategy as well. Considering the overall geopolitical situation, economic development may be complemented by common prosperity in Northeast and Southeast Asia as a whole. Once the cross-Strait common market is established in the foreseeable future, it would have a more dynamic strategic position towards other economic spheres such like Japan and Korea. 
